\title{
BAPTIZING THEOSIS: SKETCHING AN EVANGELICAL ACCOUNT
}

\author{
R. LUCAS STAMPS
}

\begin{abstract}
This essay explores some of the dogmatic challenges involved in developing a distinctively evangelical account of the doctrine of theosis, that is, humanity's participation in the life of God. After offering some preliminary clarifications regarding the terminology of theosis, the paper sketches in broad strokes how an account of theosis might take shape within the structures of evangelical theology. David Bebbington's famous evangelical quadrilateralbiblicism, crucicentrism, conversionism, and activism—serves as the basic framework (Bebbington 1989: 1-19). It will be argued that evangelical theology can accommodate a version of theosis within this structure, but that evangelicals' understanding of these categories may require some 'flexing' in order to make room for a more Christocentric and participatory conceptualization of redemption, one that culminates in the beatific vision of the redeemed when 'God will be all in all' (1 Cor 15:28). The final section of the paper points to a pair of important figures who may serve as resources for an evangelical retrieval of theosis.
\end{abstract}

KEYWORDS: theosis, evangelical, Biblicism, crucicentrism, conversionism, activism

\section{Introduction}

In a 1997 article in the Journal of the Evangelical Theological Society, Robert Rakestraw examined the ancient doctrine of theosis from an evangelical perspective (Rakestraw 1997). After noting some concerns with theosis, Rakestraw argues that the benefits of retrieving the doctrine outweigh any potential costs. He maintains that theosis can be firmly anchored in the New Testament, especially the writings of Paul, and he suggests that more exegetical and theological work needs to be done in order to develop a thoroughgoing evangelical account of the doctrine. In the nearly two decades since the publication of Rakestraw's article, the doctrine of theosis has experienced something of a revival of interest in contemporary dogmatics. A growing number of evangelicals have indeed explored the ways in which this doctrine might be developed along Reformed and/or evangelical lines,

* R. Luke Stamps (PhD 2014, The Southern Baptist Theological Seminary) is Associate Professor of Christian Theology at Anderson University in Anderson, South Carolina. Email: rlstamps@andersonuniversity.edu. 
but many evangelicals remain hesitant, wondering how this seemingly foreign doctrine might be woven into the tapestry of evangelical theology.

This essay explores some of the dogmatic challenges involved in developing a distinctively evangelical account of the doctrine of theosis, that is, humanity's participation in the life of God. After offering some preliminary clarifications regarding the terminology of theosis, the paper sketches in broad strokes how an account of theosis might take shape within the structures of evangelical theology. David Bebbington's famous evangelical quadrilateral-biblicism, crucicentrism, conversionism, and activism-serves as the basic framework (Bebbington 1989: 1-19). It will be argued that evangelical theology can accommodate a version of theosis within this structure, but that evangelicals' understanding of these categories may require some 'flexing' in order to make room for a more Christocentric and participatory conceptualization of redemption, one that culminates in the beatific vision of the redeemed when 'God will be all in all' (1 Cor 15:28). The final section of the paper points to a pair of important figures who may serve as resources for an evangelical retrieval of theosis.

One of the convictions underlying this structural approach is that any theologically meaningful and historically faithful retrieval of theosis cannot view the doctrine simply as an auxiliary or an add-on to evangelical theology. Instead, we must consider how the doctrine would fit within the structures of evangelical theology as a whole. We would do well to heed Andrew Louth's warning that Western appropriations of the theosis have often 'assimilated it to an alien framework', resulting in an unsurprisingly awkward 'fit' (Louth 2007: 33). Still, given the presence of theosis themes in the Western traditions, the East can hardly claim a monopoly on the doctrine, even if they have often followed more consistently its patristic development. But the challenge for evangelicals seeking to appropriate a theosis doctrine will be to show how the doctrine can be worked through the whole fabric of evangelical theology. The following reflections offer a preliminary attempt to sketch out how this appropriation might take shape.

\section{Terminology}

But, first, we must address the pressing question of terminology. What do we mean when we speak of theosis? What is the sine qua non of the doctrine? Some have tried to draw distinctions between the terms theosis, deification, and divinization. To avoid confusion, Jaroslav Pelikan makes a case for preserving the transliteration, theosis, because it avoids the potential confusion that attends English terms like deification and divinization (Pelikan 1990: 164). Others, however, have suggested that these distinctions are less than helpful and that the more telling question is how the doctrine is worked through the whole fabric of Christian doctrine. Kyle Strobel, for instance, 
argues that 'it is often more helpful to locate the organizational structures of theosis than to provide a terse definition', suggesting that we must take into consideration how the doctrine is pressed through the various loci of an individual's theology (Strobel 2012: 262).

In any event, it must be stated up front that the common fear expressed by many Protestants that theosis necessarily involves a blurring of the lines between creaturely existence and the divine essence is ill-founded. The classic patristic and Eastern Orthodox expressions of theosis have carefully avoided these conclusions. The well-known distinction between the divine essence and the divine energies, systematized by Gregory Palamas, expresses the mature Orthodox view on this front. According to this rendering, human beings may participate in the divine energies (the uncreated effulgence of God's glory) but cannot penetrate the absolutely incomprehensible and incommunicable divine essence. While many (though not all) in the Western traditions have rejected this distinction between essence and energies, it at least highlights the care taken in the East to avoid the notion that human beings somehow become one with the essence of God, while at the same time affirming a real participation in God himself. Theosis, then, is not apotheosis; it is not the transformation of humanity into non-humanity, as was often the case in ancient paganism.

Western theologians emphasizing theosis have had to employ a similar apparatus, in any event, sometimes distinguishing between the divine nature or the divine relations, on the one hand, and the divine essence, on the other. Rowan Williams suggests that the theosis doctrine has produced two distinct strands: one highlighting participation in the divine attributes and one emphasizing participation in the relationships between the divine persons (Williams 1983: 106). In a Reformed context, Strobel demonstrates how both Calvin and Edwards drew a distinction between the divine nature, in which humans do participate, and the divine essence, which is utterly incommunicable (Strobel 2016: 372-73). Strobel shows how Edwards' own idiosyncratic Trinitarianism allowed him to make room for both kinds in Williams' typology. But in either case, all orthodox versions of theosis must set up some safeguard for the incommunicability of the divine essence. So, in short, one of the most common evangelical objections to theosis, namely, that it would result in some kind of crude confusion of Creator and creature, turns out to be one of the easiest to dismiss.

So what then is theosis? We might state as a working definition that theosis is redeemed humanity's participation in the life of God. As noted above, this participation has sometimes been cashed out in terms of a sharing in the divine attributes and at others in terms of a sharing in the divine relations. As we think about how evangelicals might fit this doctrine within our own theological categories, we should stress that theosis cannot be too quickly equated 
with important themes like union with Christ or communion with God, at least if these are conceived of too narrowly as merely legal or experiential categories. Roger Olson critiques certain evangelical appropriations of theosis precisely along these lines (Olson 2007: 186-200). Instead, participation involves more than (but certainly not less than) a faith relationship with God through Jesus Christ. It also involves some kind of real participation in the life of God.

Again, this should not be misunderstood to mean that the Creator/creature distinction is blurred, far less that it is obliterated. It simply means that theosis involves a transformation, even transfiguration, of human nature through the incarnational work of Jesus Christ. Irenaeus' early reflections are indicative: God became what we are so that we might become what he is (Irenaeus 1997: 60). In Christ, the redeemed become more than they could have been otherwise; in the one true man, the incarnate Christ, they become more fully and truly human, and thus more fully and truly reflect the image of God. The Cappadocian Fathers sometimes spoke of theosis using the metaphor of a mirror that when polished reflects the glory of God. Thus, participation in God means coming to share more fully in his communicable attributes in a creaturely mode. It need not entail an approval of the Lutheran genus maiesticum (genus of majesty), as some Reformed critics have suggested (McCormack 2010: 504-29). In other words, evangelicals of a more Reformed persuasion need not surrender their commitment to the classical understanding of the communicatio idiomatum: that divinity and humanity are united but not confused, even in the person of Christ, much less in redeemed humans. Neither in Jesus nor in the redeemed is humanity somehow translated into the divine essence.

Even if we were to speak about theotic participation in ontological terms, this would not threaten the integrity of the Creator/creature distinction. Louth explains that the Orthodox wish 'to speak of this change in terms of ontology, not because this change involves a conversion into something other than human, but rather because the change involved is fundamental, radical, a rebuilding of what it is to be human from the roots up' (Louth 2008: 40). Theosis assumes the biblical story of creation, fall, and restoration in Christ. Humans were made in the divine image but in a state of immaturity, with the potential for a heightened, glorified existence. This possibility was lost by the disastrous decision of humanity to grasp after divine knowledge apart from God's will. And through the incarnation and reconciling work of Jesus Christ, the way is reopened for humanity to attain to life in God. Thus, theosis demands a robust biblical theology, which may be an avenue through which evangelicals can retrieve their own expressions of the doctrine. It is the biblical teaching on theosis that we now turn. 


\section{Biblicism}

In his history of modern British evangelicalism, historian David Bebbington suggested that four characteristics have especially marked the evangelical movement: 'conversionism, the belief that lives need to be changed; activism, the expression of the gospel in effort; biblicism, a particular regard for the Bible; and what may be called crucicentrism, a stress on the sacrifice of Christ on the cross. Together they form a quadrilateral of priorities that is the basis of Evangelicalism' (Bebbington 1989: 2-3). Bebbington's quadrilateral is far from exhaustive, and evangelical historians and theologians may wish to nuance or expand upon his list of evangelical priorities. Nevertheless, in my view, these characteristics remain a helpful starting point, not necessarily for understanding the whole of evangelical theology, but at least for understanding that cocktail of theological emphases that have distinguished the Anglo-American evangelical movement since its beginnings in the $18^{\text {th }}$ century revivals. These categories will frame our discussion of how theosis might fit within a distinctively evangelical theology.

Given the epistemological priority placed upon Scripture in evangelical doctrine, we will begin with the third side of Bebbington's quadrilateral: biblicism. The most pressing question evangelicals will wish to answer is, does Scripture teach a doctrine of theosis? The late church historian Jaroslav Pelikan claimed that the two principle prooftexts for theosis are Psalm 82:6I say, you are gods-and 2 Peter 1:4-partakers of the divine nature (Pelikan 1974: 10). Patristic and Orthodox interpreters have also grounded their view of theosis in the Genesis creation account, which speaks of man being made in the image and likeness of God. A host of other texts have been cited as well. The list of references marshaled by Jonathan Edwards in his discussion of participation in God is impressive. In addition to 2 Peter 1:4, Edwards mentions passages that speak of ...

God dwelling in them, and they in God (I John 4:12, 15-16, and ch. 3:21), and having Christ in them (John 17:21; Rom. 8:10), being the temples of the living God (II Cor. 6:16), living by Christ's life (Gal. 2:20), being made partakers of God's holiness (Heb. 12:10), having Christ's love dwelling in them (John 17:26), having his joy fulfilled in them (John 17:13), seeing light in God's light, and being made to drink of the river of God's pleasures (Ps. 36:8-9), having fellowship with God, or communicating and partaking with him (as the word signifies) (1 John 1:3) (Edwards 1959: 203).

Doing justice to any one of these texts is beyond the scope of this brief essay. No doubt, 2 Peter 1:4 is especially relevant for developing an evangelical doctrine of theosis. James Starr's work on this text in its Hellenistic context is especially insightful. Starr shows how 2 Peter deliberately builds upon theosis categories from the Hellenistic milieu, but restructures them around a more 
Pauline epistemological, ethical, and eschatological vision (Starr 2007: 8192). Against this backdrop, Starr offers a careful exegesis of the 2 Peter 1. Believers are said to be partakers or sharers (koinonoi) of the divine nature. What is this divine nature? Starr observes at least five characteristics of the divinity in which the redeemed participate: righteousness or justice (1:1), power (1:3), glory (1:3b), excellence or virtue (1:3b), and incorruptibility (1:4). Participation in these divine attributes is possible only through 'the knowledge of our Lord Jesus Christ' (1:8), which then produces the fruit of the grace-enabled virtuous life. Through the diligent practice of these virtues we can be confirmed in our election and be assured of our 'entrance into the eternal of kingdom of our Lord and Savior Jesus Christ', when our participation in the glory of God will be even more fully realized.

At any rate, evangelical appropriations of the doctrine of theosis should not be limited to simple prooftexting. This would be a biblicism of the unhelpful variety-one that relies on an overly simplistic understanding of what counts as biblical and that ignores the rich resources of the history of interpretation. Thus, evangelicals would do well to think beyond a list of prooftexts and to reflect more carefully on the broader biblical and theological themes that might inform an evangelical doctrine of theosis. For example, what might the Reformed teaching on Adam's probationary period and the promise of glorification held out to him say about the biblical expectation for a transformed human experience? Furthermore, most recognize that the eschaton will be an advance upon the proton and that the resurrection and glorification of believers will involves some kind of fundamental transfiguration of human experience (Barcellos 2013). A biblical theology of the image God-its creational design, its distortion through sin, its restoration in Christ, and its perfection in glorification-might also prove useful. How might these soteriological and eschatological givens influence an evangelical account of theosis? Additionally, the Pauline themes which loom large in evangelical theology may also prove to be a treasure trove of resources for developing a doctrine of theosis. Rakestraw points to Paul's teaching on union with Christ and the Spirit's renewing work among other themes that may point in this direction (Rakestraw 1997: 267-68). Furthermore, the Johannine vision of seeing and being like the glorified Christ adds a further stroke to the biblical portrait of glorified existence (1 John 3:1-4). In short, evangelicals who turn their attention to Scripture with a view to humanity's participation in God will surely find no shortage of texts and themes that will inform their understanding of this classical doctrine.

\section{Crucicentrism}

As Bebbington explains, evangelicalism has been characterized by an intensive focus on the reconciliation of the world through the atoning death of 
Jesus Christ: 'To make any theme other than the cross the fulcrum of a theological system [is] to take a step away from Evangelicalism' (Bebbington 1989: 15). Evangelical atonement theology has been overwhelmingly substitutionary in nature. The central message of Christianity according to standard evangelical theology is that God has made a way for fallen humanity to be reconciled to himself through the death of Christ, who bore our penalty as our representative and substitute. Salvation in this scheme is fundamentally an external reality, a transaction that takes place extra nos, outside of us, through the double imputation of our sin to Christ and his perfect righteousness to us. So how does theosis fare in a context like this?

Some would point to this distinctive as precisely the point at which evangelicalism and the patristic soteriology part ways. Salvation is not a synergistic cooperation between God's initiative and human effort, but a monergistic work of God for us and on our behalf, which then produces as its fruit the human response of faith and obedience. If the center of gravity for evangelical soteriology is the atonement, the fulcrum for patristic and Eastern soteriology is the incarnation. Again, Irenaeus: God descended to man, so that man might ascend to God. So are we at an impasse? Can evangelical crucicentrism make room for a more incarnational and participatory soteriology?

I see no reason why evangelicalism cannot accommodate a more comprehensive vision of what constitutes the redemptive work of the incarnate Christ. Perhaps we could expand our crucicentric emphasis into a more Christocentric approach to salvation. Indeed, Reformation theology already has the resources to inform this expansion. Calvin and the Reformed tradition have certainly stressed the 'whole course' of Christ's obedience (Calvin 1960: 507). Salvation is effected not merely by the atoning death of Christ but also by his incarnation, his perfect life of law-keeping obedience, his victorious resurrection from the dead, his ascension to the heavenly sanctuary, his session at the Father's right hand, his sending of the Spirit, his ongoing priestly intercession, and his future return in power and glory. Furthermore, this holistic work of Christ becomes ours through covenantal union with Christ, effected by the Holy Spirit, which brings about a holistic participation in God through Jesus Christ. Whatever Christ experienced is experienced by his people as well. If Christ has died, we have died with him. If Christ was raised from the dead, we have been raised with him. If Christ has been installed at the right hand of power, we too have been seated with him in the heavenlies. 'For you have died, and your life is hidden with Christ in God. When Christ who is your life appears, then you also will appear with him in glory' (Col 3:3-4).

The Lutheran tradition also has resources for understanding the fulsome work of Christ on our behalf and for incorporating a holistic under- 
standing of creaturely participation of in the life of God. One does not have to agree with all of the conclusions of the Finnish school of Lutheran interpretation in order to appreciate Luther's holistic understanding of human redemption (Mannermaa 2005). So in sum, I see no reason why Reformational Protestants must choose between a cross-centered understanding of the Christian faith and a more comprehensive understanding of the person and work of Christ in which his cross work is made intelligible. Indeed, one could argue that in the NT cross-language is essentially shorthand for this broader incarnational work of Christ.

Part of what will be needed in an evangelical account of theosis is a much more central role given to the doctrine of incarnation. As T. F. Torrance explains, "our "deification" in Christ is the obverse of his "inhominization" (Torrance 1995: 189). Or, as Torrance scholar Myk Habets puts it, our union with Christ is 'the soteriological correlate to the christological notion of the hypostatic union' (Habets 2010: 135). Our mystical union with Christ that culminates in our glorification at the resurrection of the dead is grounded in the hypostatic union of deity and humanity in the person of the incarnate Son. This is not to say that theosis produces additional hypostatic unions, one for each redeemed person. The hypostatic union is sui generis inasmuch as the person of Christ is consubstantial with God in his very essence. But the hypostatic union is correlative to theosis in that the redeemed are taken into the life of God precisely by union with the Incarnate God. This Christological focus also guards against any radical notions of theosis that might blur the lines between creator and creature. In the patristic and Reformed view of the communicatio idiomatum, not even the human nature of Christ becomes one with the divine essence, even if his person is one with that selfsame essence. Each nature retains its own integrity even as the human nature is lifted up into the life of God.

\section{Conversionism}

What about the evangelical emphasis on conversionism? For evangelicals, every human being, because of the guilt and corruption of sin, stands in need of a radical change. Every individual stands before God on their own two feet, so to speak; no one will receive salvation because of the faith of her parents, her church, or her culture. Everyone has a duty before God to repent of sin and believe in the gospel of Jesus Christ. And the promise of the gospel is that those who do repent and believe will receive forgiveness and transformation by the grace of God.

The topic of conversion is part of a broader conversation regarding the ordo salutis, or the order of salvation. Conversion is the obverse of regeneration; it is the human response to the divine work of initiating grace. Those who are thus regenerated and converted to Christ share in all of the salvific 
blessings of Christ: justification, the forensic declaration that sinners are in the right before God; sanctification, the transformative work of God in which humans actively participate and by which sinners are progressively conformed to God's holiness; adoption, the change in identity and inheritance ratified by inclusion in the family of God; and glorification, the radical transfiguration of human nature through the resurrection of the dead at Christ's Second Coming.

So where does theosis fit into this standard evangelical scheme? Sanctification and glorification are the obvious places where we see the transformative elements of salvation at work, but even the more legal categories of justification and adoption should not be artificially cut off from the broader work of renewal that conversion signals. Dogmatically, perhaps the most difficult problem evangelical soteriology must face when it comes to the doctrine of theosis is the precise relation between the forensic and the transformative, or participatory, elements of the ordo salutis. Orthodox theologian, Andrew Louth, states this Protestant concern well: 'Negatively it has often been claimed that deification stands in the sharpest possible contrast to the biblical doctrine of justification and represents most clearly the way in which Greek and Orthodox has strayed from authentic Christianity' (Louth 2007: 32).

But this is a discussion that is internal to evangelical theology quite apart from any ecumenical dialogue with Eastern themes. Many Reformed theologians, for example, have argued that the fundamental soteriological category for both Paul and Calvin is union with Christ. If we privilege union, rather than justification as the hub of soteriology, then we need not choose between legal and transformative categories. Both are rooted in our union with Christ. This union with Christ unfolds in three moments, as it were: the eternal moment of divine election, the incarnational moment of Christ's redeeming work, and the existential moment of personal conversion. And this union is twofold in nature: it is a forensic or legal union, by which God reckons the elect to be federally or covenantally bound to Christ; and it is a mystical or personal union, by which believers share in the life of Christ organically by the internal work of the Holy Spirit. [This last emphasis constitutes another lacuna an evangelical doctrine of theosis must fill: the pneumatological aspects of theosis. Studies of Edwards's doctrine of theosis have pointed to his unique contribution along these lines (see, for example, Hastings 2015).]

Some Reformed evangelicals, however, have questioned the propriety of displacing forensic categories with unitive themes. Michael Horton, for example, has made a robust argument for preserving the logical priority of justification in Reformed soteriology (Horton 2007). But Horton also wants to make room for the transformative elements of the doctrine of salvation, 
even for a doctrine of theosis conceived along the lines of 'covenantal participation (koinoinia)' (Horton 2007: 181-215). So even if you privilege forensic categories or give them logical priority, you can still make room for a robust theology of participation. Horton has even tapped speech-act theory as a possible mechanism for explaining the relation of the forensic to the participatory. The legal declaration of justification proclaimed in the external call of the gospel is made effective by the Spirit of God in the hearts of the elect in such a way that the gospel becomes a word that does what it says. The locution 'God justifies the ungodly' has the illocutionary force of conversion in the hearts of the elect with the perlocutionary effect of regeneration and life transformation (Horton 2007: 240-42). In this scheme, the forensic category has a kind of logical priority: the legal problem of sin and judgment has to be solved before the full blessings of participation can flow to the redeemed. But the participatory category is in no way diminished as a result. In this understanding, justification is the ground and means of deification. Or to state it in the reverse, deification is the goal of justification.

Similarly Michael Allen writes: 'Myopic focus on forensic declaration is a genuine error... Much better to say, not that justification is both forensic and formative, but that the gospel involves not only justification (its ground) but also sanctification's conclusion in glorious participation in God (its goal)' (Allen 2013: 51). So the strictly legal understanding of justification is preserved, but not at the expense of justification's end and the gospel's goal: participation in the life of God. Indeed, in recent years, Reformed theologians have been engaged in an interesting and quite fruitful debate about how theosis might within a Reformed framework. One thinks especially of the works of Gannon Murphy, Myk Habets, Todd Billings, Julie Canlis, and Carl Mosser on this front (though there has been some pushback on the part of Bruce McCormack among others; see the bibliography for the relevant sources on this debate).

\section{Activism}

The final side of Bebbington's quadrilateral is activism, that is, the evangelical emphasis on the necessity of a life of obedience, growth in holiness, evangelism, and service to others. Good works are necessary, not as the ground of acceptance before God, but as the fruit of a converted life. The Pauline teaching on justification by faith and the broader New Testament emphasis (including in Paul) on a final judgment according to works has always been a pressure point in Protestant theology. On the one hand, justification is a legal declaration made by God apart from works, solely on the basis of Christ's righteousness; but on the other hand, good works are in some sense necessary for final salvation in that they provide the indispensable, confirming evidence that a person is indeed justified by faith in Christ 
(Schreiner 2010). So in short, a life spent in pursuit of love and good deeds is the essential path for the redeemed on their pilgrimage to the heavenly city.

So what role should this evangelical emphasis on grace-enabled activism play in the development of an evangelical account of theosis? An active faith has always been a part of theosis doctrine all the way back to the Cappadocian Fathers. Gregory of Nyssa, for example, conceives of theosis as the endless pursuit, beginning in this life and continuing by increments into eternity, of creaturely participation in God. For Gregory, this participation in God is attained through the contemplative life but also through the pursuit of virtue. Gregory writes, 'whoever pursues true virtue participates in nothing other than God, because he is himself absolute virtue' (Gregory of Nyssa 1978: 31). This creaturely ascent to God is preceded by God's gracious work in Christ, and it will finally culminate in the reconstitution (apocatastasis) of all things at the return of Christ. Still, there is a strong synergistic conception of salvation that attends this patristic and Eastern soteriology. A more Reformational account of theosis will place less emphasis on the powers inherent in the human will and will more clearly ground the subjective appropriation of salvation in its objective accomplishment in Christ. But evangelical theology shares in common with Gregory an emphasis on an experiential Christianity and the pursuit of the virtuous life. So having made some necessary adjustments, I see no reason why evangelicals cannot affirm what Orthodox theologian Vladimir Lossky writes about the goal of Christian theology: 'Trinitarian theology is thus a theology of union, a mystical theology which appeals to experience, and which presupposes a continuous and progressive series of changes in created nature, a more and more intimate communion of the human person with the Holy Trinity' (Lossky 1957: 67).

\section{Resourcing Evangelical Theosis}

When seeking to develop a distinctively evangelical appropriation of theosis, where should evangelical theologians turn for helpful resources within our own tradition? Is there precedent for such a doctrine within evangelical Protestantism? Certainly evangelicals, as inheritors of the great gospel truths recovered in the Protestant Reformation, will wish to wrestle with the growing body of literature that seeks a retrieval of these themes in the Reformers themselves. Readers may consult the bibliography for some of the more relevant sources on the themes of participation in Luther and Calvin. This material is not uncontested, of course, and the debate concerning how and to what extent deification themes figured in Reformation thought is ongoing. But surely all must concede that these themes are present in some sense and to some extent in the soteriological programs of the great Reformers. They did, after all, deal with the very biblical texts and motifs that led the 
church catholic to these doctrines in the first place. But in addition to these Reformation-era sources, are there any evangelical voices who sounded this trumpet closer to home, as it were? In this final section, I wish to highlight the works of two evangelical giants, whose theological visions continue to shape contemporary evangelical Protestantism: Jonathan Edwards and John Wesley. What follows is admittedly cursory, but readers interested in these theotic accounts may consult the primary and secondary literature in the bibliography.

Jonathan Edwards is frequently heralded as the greatest theologian/philosopher the American continent has ever produced, and his theological vision remains of interest to both scholars and laypeople alike. As with other influential thinkers, scholars often search for a central or integrative motif that sums up Edwards's entire theological project. More often than not, this quest for a center tends to obscure more it illuminates. But it is noteworthy that some scholars have identified participation as a central theme in Edwards's theology. Ross Hastings, for example, has suggested that Edwards's thought can be mapped along three central unions: the union of the divine persons, the union of divinity and humanity in the person of Christ, and the union of the redeemed with the Triune God-with the Holy Spirit serving as the principle of all three unions. The last of these unions, 'the participational union of the saints, or theosis', Hastings argues, 'influences Edwards's view of salvation to such an extent that it makes ecumenical dialogue possible on the matter of justification and sanctification' (Hastings 2007: 2). We have already highlighted Edwards's appeal to Scripture to defend the notion that redemption entails a participation in the divine nature, of life in Christ, and Christ in us. Edwards speaks of glorification in explicitly theotic terms: '[T]he saints are exalted to glorious dignity, even to union and fellowship with God himself, to be in some respects divine in glory and happiness' (Edwards 1994: 241). Elsewhere, Edwards speaks of the goal of the Christian life in participational terms: 'so the new nature that is in the saints will never be at rest, till there is a perfect union with God and conformity to him, and so no separation, or alienation, or enmity remaining. The holy nature in the saints tends to the fountain whence it proceeds, and never will be at rest, till the soul is fully brought to that fountain, and all swallowed up in it' (Edwards 2001: 692).

Some of the most important work on the theosis theme in Edwards is being done by evangelical theologian Kyle Strobel. In a pair of articles appearing in the Harvard Theological Review, Strobel explores the theological architecture of Edwards's thought that gives shape to his doctrine of participation. Much of Edwards's doctrine of theosis hinges upon his imaginative (and, in many ways, idiosyncratic) understanding of the divine persons and his use of psychological analogies to explicate the doctrine of the Trinity. 
This Trinitarian grounding of theosis allows Edwards to argue for the saints' union with both the divine nature (but not the divine essence) and the relations of the divine persons, without surrendering the Reformed commitment to the communicatio idiomatum, as Strobel demonstrates. The details of Edwards's Trinitarian apparatus for the doctrine of theosis need not deter us here, but the integral place he gives to a theology of union and participation as the outworking of the life of the Trinity and of the union of divinity and humanity in the person of the Son provide a useful model for an evangelical appropriation of theosis that is woven into the whole system of Christian doctrine. Furthermore, Edwards stirring and poetic vision of the end of redemption as an absorption into the fountain of divine love remains an inspiration for many. It may yet prove useful for an evangelical retrieval of theosis as well.

John Wesley, the father of the Methodist movement, also developed a soteriological vision that made room for theosis themes. Wesley scholars debate the precise influences that fed the unique theology of Wesley and his vision for Christian holiness. Glen O'Brien has provided a helpful catalogue of Wesleyan appraisals of these influences (O'Brien 2013: 35-53). As O'Brien notes, Albert Cook Outler was one of the first to suggest that Wesley was deeply indebted to the Fathers of the first five centuries as he developed his own theological program (Outler 1964: viii-ix). Randy Maddox has gone further in arguing that Wesley's theology was specifically indebted to Eastern Orthodox influences to such an extent that is impossible to identify Wesley in exclusively Western terms. O'Brien notes, however, that these proposals have not gone unchallenged in Wesley studies. Kenneth J. Collins, for example, has argued for influences that were more proximate to Wesley's own day, namely, the Anglican tradition from which the Wesleyan movement emerged-an Anglicanism which was, in turn, 'already steeped in the Greek Fathers' (O'Brien 2013: 39).

For his part, O’Brien examines the deep 'resonance' (as opposed to a direct 'influence') between Wesley's soteriological vision and that of the great fourth-century Father, Athanasius. Both developed a Trintiarian doctrine that gave priority not to speculation about God's inner life but rather to the revelation of the divine persons in the economy of redemption. And, especially significant for our purposes, both developed a vision of the Christian life that was oriented toward the renewal of the believer in union with God. As Wesley writes,

By salvation, I mean, not barely (according to the vulgar notion) deliverance from hell, or going to heaven, but a present deliverance from sin, a restoration of the soul to its primitive health, its original purity; a recovery of the divine nature; the renewal of our souls after the image of God in righteousness and true holiness, in justice, mercy and truth (quoted in O'Brien 2013: 49). 
O'Brien notes that Wesley's own conversion experience-when his heart was 'strangely warmed'-involved not only an interaction with Luther's Preface to Romans but also meditation on 2 Peter 1:4, the locus classicus for theologies of participation. O'Brien sees theosis as the 'organizing principle of [Wesley's] ordo salutis' (O'Brien 2013: 50), and Outler speaks of 'divinehuman participation' as the 'central theme' in Wesley's theology and praxis (cited in O'Brien 2013: 51). Thus, Wesley's soteriological program joins with Edwards's as a possible resource for evangelical appropriation of theosis, even for those who may not wish to follow him all the way in his theology of entire sanctification. To sum up, evangelicals can look to some the brightest lights in their own tradition in order to develop a distinctively evangelical version of theosis. To return to Bebbington's quadrilateral, in following Edwards's and Wesley's lead, an evangelical appropriation of theotic themes will be anchored in the biblical text, centered on the redemptive work of the Incarnate God, and oriented towards a desire for all to enter into this saving work and the life of holiness and love that it produces.

\section{Conclusion}

Theosis, participation in the life of God, reaches its apogee only in eternity, but it begins to take flight even in this life, as believers are united to God in Christ by the power of the Holy Spirit and as they make diligent use of the means of grace: reading and hearing the Word of God; communing with God in prayer; receiving the grace of the sacraments; and participating in the body of Christ. Theosis is an ancient Christian theme and one that is most commonly identified as an Eastern Orthodox or Roman Catholic doctrine. But participation themes are present in the Reformers themselves and have precedent in the evangelical traditions that came in the Reformers' wake. The structures of evangelical theology-biblicism, crucicentrism, conversionism, and activism-are, in a sense, ready-made to accommodate a version of theosis, even if they must be conceived in broad enough terms to incorporate the whole of the church's reflections on the redeeming and reconciling work of the Triune God. Individual evangelical theologians and traditions may develop distinct versions of theosis, but theologians such as Edwards and Wesley provide instructive examples of how this appropriation might take shape. Much work remains to be done in order to continue developing an evangelical doctrine of theosis, not only at the scholarly level but also in ways that will influence evangelical preaching, piety, and mission. If this work is to be fruitful, evangelicals will need to keep in their gaze the rich biblical portrait of redemption that culminates in the beatific vision of God at the parousia of Christ, when all of the redeemed of all of the ages will know even as they are known (1 Cor 13:14) and when they will be transfig- 
ured into the image of their incarnate, crucified, and risen Savior because they will see him as he is (1 John 3:2).

\section{Bibliography}

Allen RM (2013) Justification and the Gospel: Understanding the Contexts and Controversies. Grand Rapids: Baker Academic.

Barcellos RC (2013) Better than the Beginning: Creation in Biblical Perspective. Palmdale, CA: Reformed Baptist Academic.

Bebbington DW (1989) Evangelicalism in Modern Britain: A History from the 1730s to the 1980s. London: Routledge.

Billings JT (2005) John Calvin: United to God through Christ. Harvard Theological Review 98(3): 315-334.

Blackwell B (2016) Christosis: Engaging Paul's Soteriology with His Patristic Interpreters, rev ed. Grand Rapids: Eerdmans.

Calvin J (1960) Institutes of the Christian Religion. Louisville: Westminster John Knox.

Canlis J (2010) Calvin's Ladder: A Spiritual Theology of Ascent and Ascension. Grand Rapids: Eerdmans.

Christensen MJ and Wittung JA, eds (2007) Partakers of the Divine Nature: The History and Development of Deification in the Christian Traditions. Grand Rapids: Baker Academic.

Edwards J (2009) Religious Affections. In Smith JE (ed) The Works of Jonathan Edwards, volume 2. New Haven: Yale University Press.

Edwards J (2001) Sermons and Discourses: 1734-1738. In Lesser MX (ed) The Works of Jonathan Edwards, volume 19. New Haven: Yale University Press.

Edwards J (2000) The 'Miscellanies' 501-832. In Chamberlain A (ed) The Works of Jonathan Edwards, volume 18. New Haven: Yale University Press.

Finlan S and Kharmalov V, eds (2006) Theosis: Deification in Christian Theology. Eugene, OR: Pickwick.

Gregory of Nyssa (1978) The Life of Moses. The Classics of Western Spirituality. Mahwah, NJ: Paulist.

Grenz SJ (2001) The Social God and the Relational Self: A Trinitarian Theology of the Imago Dei. Louisville: Westminster John Knox.

Habets M (2006) Reforming Theosis. In Filan S and Kharlamov V (eds) Theosis: Deification in Christian Theology. Eugene, OR: Wipf \& Stock, pp. 14667.

Habets M (2009) Theosis in the Theology of Thomas Torrance. Farnham: Ashgate. 
Habets M (2010) Theosis, Yes; Deification, No. In Habets M (ed) The Spirit of Truth: Reading Scripture and Constructing Theology with the Holy Spirit. Eugene, OR: Pickwick.

Hastings WR (2015) Jonathan Edwards and the Life of God: Toward an Evangelical Theology of Participation. Minneapolis: Fortress.

Horton MS (2007) Covenant and Salvation: Union with Christ. Louisville: Westminster John Knox.

Irenaeus (1997) On the Apostolic Preaching. Crestwood, NY: St Vladimir's Seminary Press.

Kharlamov V, ed (2011) Deification in Christian Theology-Volume 2. Eugene, OR: Pickwick.

Lossky V (1957) The Mystical Theology of the Eastern Church. Crestwood, NY: St. Vladimir's Seminary Press.

Louth A (2007) The Place of Theosis in Orthodox Theology. In Christensen MJ and Wittung JA (eds) Partakers of the Divine Nature: The History and Development of Deification in the Christian Traditions. Grand Rapids: Baker Academic, pp. 32-44.

Mannermaa T (2005) Christ Present in Faith: Luther's View of Justification. Minneapolis: Fortress.

McCormack BL (2010) Union with Christ in Calvin's Theology: Grounds for a Divinization Theory? In Hall DW (ed) Tributes to John Calvin: A Celebration of His Quincentenary. Phillipsburg, NJ: P\&R, pp. 504-529.

Mosser C (2002) The Greatest Possible Being: Calvin and Deification. Scottish Journal of Theology 55(*): 36-57.

Murphy G (2008) Reformed Theosis? Theology Today 65(2): 191-212.

O'Brien G (2013) John Wesley and Athanasius on Salvation in the Context of the Debate over Wesley's Debt to Eastern Orthodoxy. Phronema 28(2): 35-53.

Olson RE (2007) Deification in Contemporary Theology. Theology Today 64(2): 186-200.

Pelikan J (1974) The Spirit of Eastern Christendom (600-1700). The Christian Tradition, volume 2. Chicago: University of Chicago Press.

Pelikan J (1990) Orthodox Theology in the West: The Reformation. In Breck J, Meyendorff J and Silk E (eds) The Legacy of St. Vladimir. Crestwood, NY: St. Vladimir's Seminary Press, pp. 159-66.

Pinnock C (1996) Flame of Love: A Theology of the Holy Spirit. Downers Grove, IL: InterVarsity.

Rakestraw RV (1997) Becoming Like God: An Evangelical Doctrine of Theosis. Journal of the Evangelical Theological Society 40(2): 257-69.

Schreiner TR (2010) Another Look at the New Perspective. Southern Baptist Journal of Theology 14(3): 6-10. 
Starr J (2007) Does 2 Peter 1:4 Speak of Deification? In Christensen MJ and Wittung JA (eds) Partakers of the Divine Nature: The History and Development of Deification in the Christian Traditions. Grand Rapids: Baker Academic, pp. 81-92.

Strobel K (2012) Jonathan Edwards and the Polemics of Theosis. Harvard Theological Review 105(3): 259-79.

Strobel K (2016) Jonathan Edwards's Reformed Doctrine of Theosis. Harvard Theological Review 109(3): 371-99.

Torrance TF (1995) The Trinitarian Faith: The Evangelical Theology of the Ancient Catholic Church. Edinburgh: T\&T Clark.

Williams R (1983) Deification. In Wakefield GS (ed) Westminster Dictionary of Christian Spirituality, pp. 106-108. 